\title{
Horizontal Crack Induced Vertical Crack Formation in Epoxy Mold Compound for Electronic Packaging
}

Syed Mohamad Mardzukey Syed Mohamed Zain ${ }^{1,2}$, Azman Jalar ${ }^{2,3}$, Maria Abu Bakar ${ }^{2}$, Fakhrozi Che Ani ${ }^{1}$ and Mohamad Riduwan Ramli ${ }^{1}$

${ }^{1}$ Western Digital ${ }^{\circledR}$

${ }^{1}$ SanDisk Storage Malaysia Sdn.Bhd.

${ }^{1}$ Plot 301A, Persiaran Cassia Selatan 1, Taman Perindustrian Batu Kawan, ${ }^{1}$ MK13, Batu Kawan, Seberang Perai Selatan, Penang, Malaysia

${ }^{2}$ Institute of Microengineering and Nanoelectronics, University Kebangsaan Malaysia, Bangi, Selangor

${ }^{3}$ Department of Applied Physics, Faculty of Science and Technology, University Kebangsaan Malaysia, Bangi, Selangor

\begin{abstract}
Epoxy mold compound (EMC) has been widely applied as the packaging material in the electronic industry. It is due to the unique property of EMC such as high temperature stability, low coefficient of thermal expansion (CTE), excellent electrical properties and manufacturability. Despite of superior properties of EMC, several failures have been reported regarding on the electronic packaging application such as crack on the body (EMC). Most of the research reported that the crack defect was originated from the moisture absorption. This research is intended to examine the phenomenon and effect of moisture absorption on the vertical and horizontal crack formation. A comparison between control and conditioned sample was studied where the conditioned sample was subjected to humidity chamber according to the Moisture Sensitivity Level 3 (MSL3) requirement. Horizontal crack occurrence was observed at the interface EMC. While vertical crack occurrence could be linked with the horizontal crack. Further analysis suggested that horizontal crack occurrence induced vertical crack occurrence. Thus, controlling moisture absorption pathway might minimize horizontal crack and prohibit vertical crack occurrence.
\end{abstract}

Keywords: BGA component; Epoxy Mold Compound; Horizontal Crack; Moisture Crack; Moisture Sensitivity Level 3; Vertical Crack

\section{Formacija vertikalnih razpok zaradi horizontalne razpoke $v$ epoksi zmesi za elektronsko embalažo}

Izvleček: Epoksi zmes (EMC) se pogosto uporablja kot embalažni material v elektronski industriji. To je posledica edinstvenih lastnosti EMC, kot so visoka temperaturna stabilnost, nizek koeficient toplotne razteznosti (CTE), odlične električne lastnosti in možnost izdelave. Kljub odličnim lastnostim EMC je bilo zabeleženih več napak pri uporabi v obliki razpok. Večina raziskav je poročala o nastanku razpok zaradi absorpcije vlage. Namen te raziskave je preučiti pojav in vpliv absorpcije vlage na nastanek vertikalnih in horizontalnih razpok. Raziskana je bila primerjava med kontrolnim in testnim vzorcem, pri čemer je bil testni vzorec izpostavljen vlažni komori v skladu z zahtevami tretjega nivoja občutljivosti na vlago (MSL3). Na površini EMC je bil opažen nastanek vodoravnih razpok. Pojav navpičnih razpok je bil povezan z vodoravnimi razpokami. Nadaljnja analiza je pokazala, da je pojav horizontalno-talnih razpok povzročil vertikalne razpoke. $Z$ nadzorom poti absorpcije vlage bi lahko zmanjšali vodoravno razpoko in s tem preprečili nastanek vertikalnih razpok.

Ključne besede: BGA zmes; Epoksi zmes; horizontalne razpoke; vertikalne razpoke; razpoka zaradi vlage; nivo občutljivosti vlage 3

*Corresponding Author's e-mail:azmn@ukm.edu.my

S. M. M. S. M. Zain et al., "Horizontal Crack Induced Vertical Crack Formation in Epoxy Mold Compound for Electronic Packaging", Inf. Midem-J. Microelectron. Electron. Compon. Mater., Vol. 51, No. 4(2021), pp. 261-266 


\section{Introduction}

Epoxy mold compound (EMC) is widely used as encapsulation materials in electronic packaging industry due to their excellent electrical properties and manufacturability. However, the reliability of EMC is a concern due to its hygroscopic in nature and has a high tendency to absorb moisture from the surrounding. At high temperature especially during the reflow process in the solder mount assembly (SMA), the absorbed moisture is rapidly vaporized and tend to exhibit 'pop-corning' issue [1]-[3].

The reflow soldering process is the most widely used method of attaching surface mount components to the printed circuit boards (PCBs) by first pre-heating the components, $\mathrm{PCB}$ and solder paste then re-melting the solder [4]-[8]. The temperature profile range during the reflow process is around $220-250^{\circ} \mathrm{C}$. The crack can be observed at high temperatures during the reflow process if the concentration of moisture within the EMC exceeds the critical value which occurs as an interfacial delamination. Several literatures have reported the crack between the mold compound and the substrate during solder reflow for various die sizes and molding compound thickness [9]-[12].

According to Groothuis, higher content of moisture may be absorbed in high glass transition temperature (Tg) material and ultimately contribute to explosive force during sudden heat [1]. The moisture that presents in the mold compound will vaporize during high temperature and stress the package. This stress induces the package to crack, which causes delamination between the mold compound and lead frame or die. In order to avoid an occurrence of this defect, the package can be baked before assembly to remove the moisture [2]. Lau reported that the crack exists at the early stage of reflow and not at the peak temperature of solder reflow. The initiation of the crack begins at the die corner due to the high stress concentrated. The baking condition for $24 \mathrm{~h}$ at $125^{\circ} \mathrm{C}$ is considerably insufficient to bake out the whole absorbed moisture [3]. Most of the research on the crack formation of EMC was focused on investigating the moisture absorption, vaporization, and delamination deformation (loss of adhesion).

A comparison between relative humidity $(\mathrm{RH})$ treated sample and without $\mathrm{RH}$ treated sample was studied where the RH treated sample was subjected to humidity chamber according to the Moisture Sensitivity Level 3 (MSL3) requirement. Ball grid array (BGA) component encapsulated with the EMC was used as the sample to investigate the orientation effect of the crack. Vertical and horizontal crack were observed and analyzed after running through the reflow process to understand crack formation inside EMC.

\section{Materials and methods}

EMC encapsulation components were used as the test samples with the size of $17 \times 17 \times 0.8 \mathrm{~mm}$ (WxLxt). The solder joint of the component was BGA and was mounted on the PCB. The EMC used was a commercially grade of electronic packaging. The EMC BGA component were subjected to the humidity chamber. The parameters of the chamber were set at $30{ }^{\circ} \mathrm{C}, 60 \% \mathrm{RH}$ for $168 \mathrm{~h}$ (Level 3-Moisture Soak Requirement) [13]. The weight of the component was measured using weight balance instrument (AND HR-250AZ) after humidity test. Subsequently, the samples were run through the manufacturing reflow oven (Pyramax150 12Z) using the actual reflow thermal profile with the maximum temperature of $250^{\circ} \mathrm{C}$. Comparatively, the normal EMC component without subjected into the humidity chamber were run through the oven together with the test samples.

The failure analysis was then performed on both samples. Prior to the analysis, the sample was i cold mounted using epoxy resin. About $50 \mathrm{~mL}$ resin was mixed with $8 \mathrm{~mL}$ hardener and was left at the ambient condition for $12 \mathrm{~h}$ to allow curing. Silicon carbide (SiC) grinding paper was used for mechanically grinding the component with the grit size of 180, 240, 600, 800 and 1200 sequentially. The final polishing was performed with alumina $\left(\mathrm{Al}_{2} \mathrm{O}_{3}\right)$ powder $(0.3 \mu \mathrm{m}$ and $1 \mu \mathrm{m})$. The optical images were evaluated using ultra-high precision digital microscope (VHX-7000 Series) from Keyence. The samples were coated using platinum prior to Field Emission Scanning Electron Microscope (FESEM) analysis to minimize sample charging. The FESEM was performed on the Hitachi SU-8030 to analyze the horizontal and vertical crack. Meanwhile, the close-up observation of the EMC on top view and side view were captured from the cross-section analysis. The size and shape of the solder balls was investigated by GE Phoenix Microme 2D X-ray.

\section{Results and discussion}

\subsection{RH moisture test}

The weight of the component increased with increasing $\mathrm{RH}$ storage. The component weight gain from $\mathrm{RH}$ test was then analyzed according to percentage of moisture absorption as shown in Fig. 1. Apparently, the moisture content of the components increased linearly with time. This behavior indicated that EMC use this study was able to absorb moisture as typical hermetic package from the epoxy based polymeric material. 


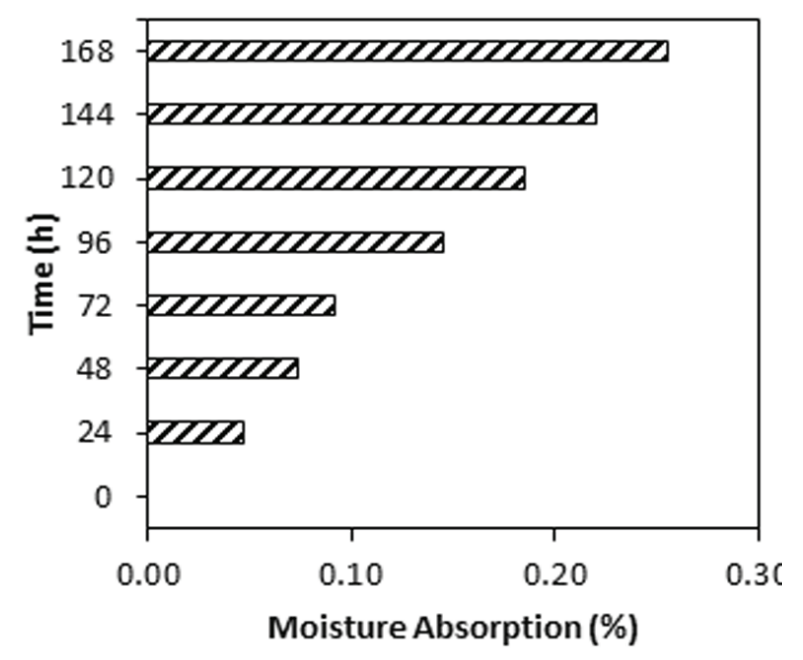

Figure 1: The moisture absorption of the samples at conditioning setting of $30^{\circ} \mathrm{C} / 60 \% \mathrm{RH} / 168 \mathrm{~h}$

\subsection{Crack occurrence time frame}

Figure 2a shows the micrograph of different size and location of solder ball from x-ray testing after reflow soldering process. The solder ball size was larger at the edge location and smaller at the middle location of the BGA. This condition might be contributed from uneven stress distribution throughout the component. From Fig. $2 b$, the solder ball at the middle showed slightly elongated than that of the edge. Interestingly, Fig. 2b also showed that vertical crack in the EMC appeared at the middle of the component. The elongation of the
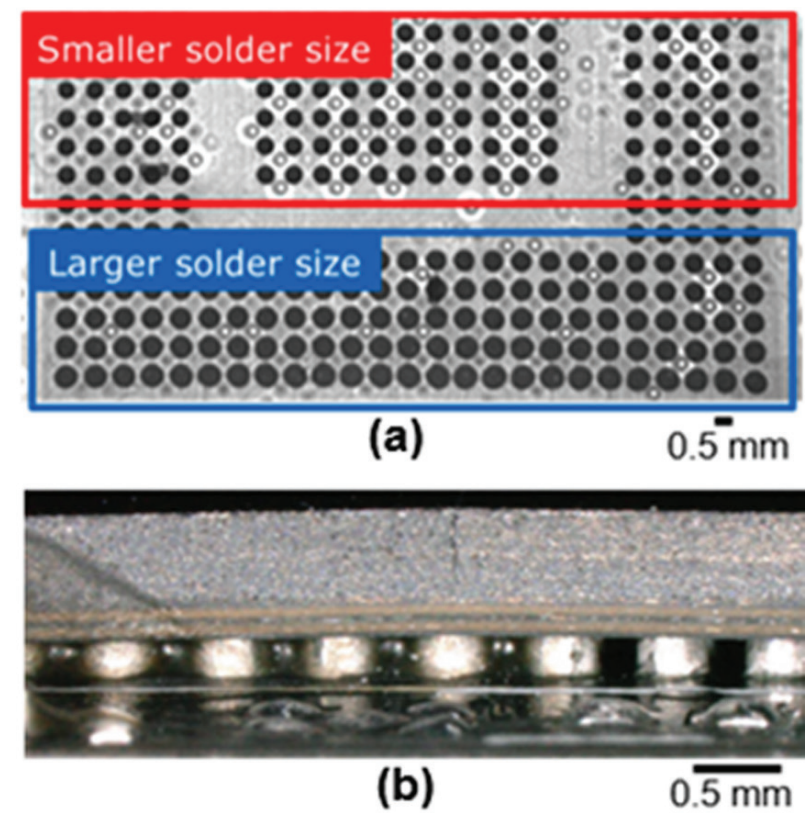

Figure 2: Micrograph of: (a) different size and location of solder ball from X-ray testing after reflow soldering process and (b) side view image of solder ball at the middle showing slightly elongated than that of the edge location solder ball at the middle suggested that the time frame of the crack occurred during reflow process. During the reflow time, the high temperature induced the formation of crack and simultaneously, the BGA were remelted. As a result, the solidified solder ball preserved the warping condition of the component.

The warping condition of the component could be clearly seen in Fig 3 that signified the different ball shape pattern along the BGA component and its enlargement of the chosen solder ball. The locations of $A$, $D$ and $E$ were the solder ball at the edge while $B$ and $C$ $\mathrm{W}$ at the middle of the component. The balls at the $A$, $D$ and $E$ showed a compressed shape, meanwhile the $B$ and $C$ indicated an elongated shape with different sizes and shapes of the solder balls array in Fig 3 were corroborated further the evidence of the crack occurrence during the reflow process at high temperatures.

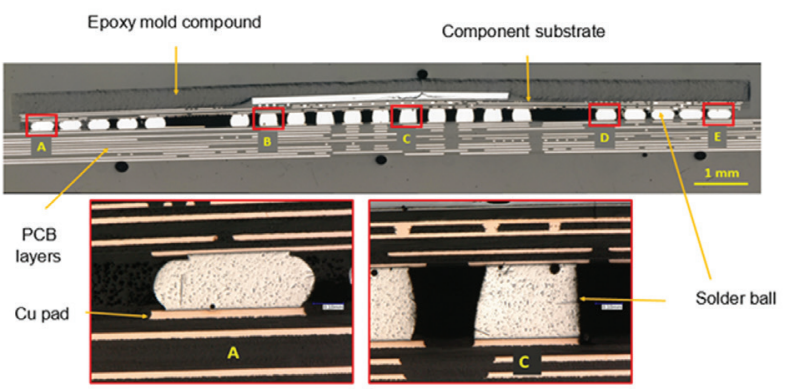

Figure 3: Cross-section of different solder ball shape along the BGA component the enlargementimages represented the compress and elongation solder balls condition

\subsection{Vertical and horizontal cracks}

Figure $4 \mathrm{a}$ and $4 \mathrm{~b}$ show crack occurrence of the sample that was subjected to the $\mathrm{RH}$ testing at 30 ${ }^{\circ} \mathrm{C} / 60 \% \mathrm{RH} / 168 \mathrm{~h}$. Fig 4 a shows horizontal crack on the EMC surface in the form of small line at the middle of the component. Whereas Fig $4 \mathrm{~b}$ shows a side view image of the component with an indication of vertical crack at the middle. It was observed that the vertical crack was perpendicular to the line crack as shown in Fig 4b.

The formation of the crack was attributed to the 'popcorning' from the moisture absorption of the EMC [1]-[3], [11-12], [15]. During the reflow process, the temperature was raised above the glass transition temperature $(\mathrm{Tg})$ of the EMC (ranging from $110^{\circ} \mathrm{C}$ to 120 ${ }^{\circ} \mathrm{C}$ ) to a temperature of approximately $220^{\circ} \mathrm{C}$ or more with the heating rate of $2^{\circ} \mathrm{c} / \mathrm{sec}$, which was required to melt the solder. At high reflow temperature, the existing moisture inside the conditioned sample vaporized into a steam. The stresses due to the thermal mismatch 
between the molding compound and the adhering materials led to the interfacial de-adhesion and followed by package cracking due to the steam pressure and hygroscopic swelling [15], [16]. This thermal stress and steam pressure cause the package to crack and resulted in a delamination between the mold compound and the lead frame or die [2].

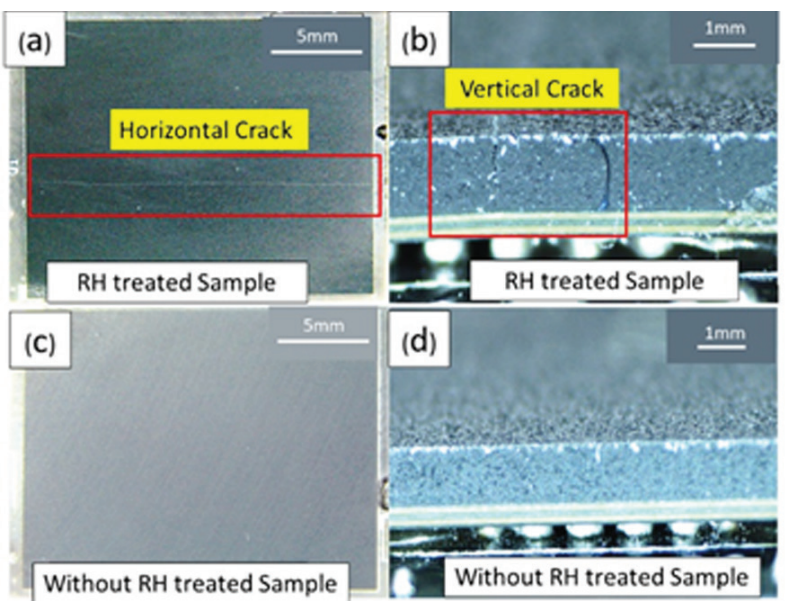

Figure 4: $(a, b)$ Crack observed on $\mathrm{RH}$ treated sample and $(c, d)$ no crack observed on non- $\mathrm{RH}$ treated sample
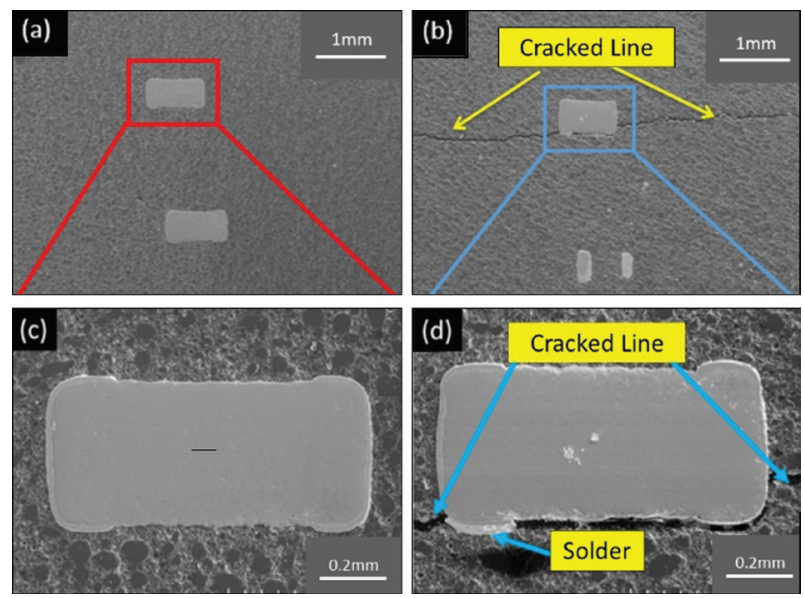

Figure 5: The SEM images of (a) top-down grinding of without $\mathrm{RH}$ treated sample (b) top-down grinding of $\mathrm{RH}$ treated sample (c) enlarged view of passive component of without RH treated sample and (d) enlarged view of passive component of $\mathrm{RH}$ treated sample

To have further understanding on the horizontal crack, the sample was ground from top until reaching the passive components. The path of the crack appearance was clearly observed alongside the passive component as shown in Fig $5 \mathrm{~b}$ for the $\mathrm{RH}$ treated sample but not on the $\mathrm{RH}$ non-treated sample (Fig. 5a). Interestingly, Fig. $5 \mathrm{~d}$ signified the abnormal existence of the solder at the terminal of the passive component (localized) alongside the crack line. It was highly anticipated that the existence of the micro-void at the passive component terminal led to this phenomenon. During the reflow process of the BGA component, the solder material of the passive component was re-melted for the second time and seeped through this micro-void pocket.

Furthermore, the existence of the micro-voids increased the tendency of the EMC to absorb moisture through non-Fickian diffusion [17]. The non-Fickian diffusion behavior was suggested due to the complex nature of the hygrothermal behavior of the polymer network. The moisture uptake may initially exhibit relatively rapid with constant diffusivity but can eventually slow down due to the variable diffusivity. The microvoids would be a place where the moisture could be concentrated in the EMC. At the high temperature, the volatized concentrated moisture along the component might escape from the EMC rapidly and thus created the horizontal crack line.

Fig. 6 shows the schematic illustration to describe vertical crack phenomena in EMC whereby moisture ingression route originated from the edge of both side component. Fig. 6 a shows that during $\mathrm{RH}$ testing, the moisture was moving in from both edge of the BGA component and trapped at the middle of BGA component. While Fig $6 \mathrm{~b}$ illustrates a formation of crack during the reflow process. In general, reflow process involves high temperature, and the concentrated moisture trap induces high pressure at the middle of the BGA component. Then the moisture trap at the middle was vaporized to accommodate pressure distribution thus the resulted in a formation of vertical crack.

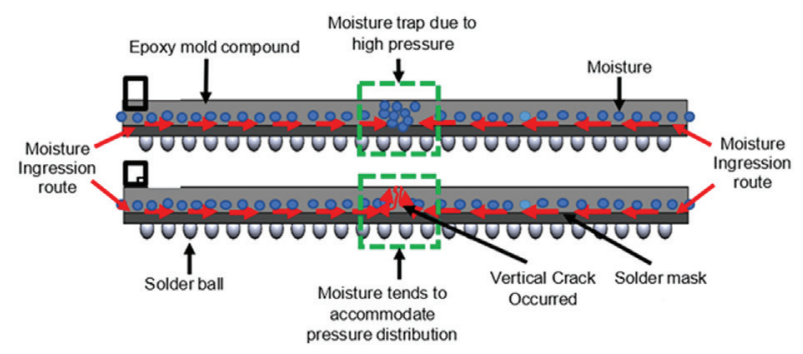

Figure 6: Schematic illustration to describe crack phenomena, $(A)$ moisture ingression route and trap at the middle, $(B)$ moisture tend to find possible route to accommodate pressure distribution

\section{Conclusions}

This current study successfully investigated the crack occurrence in term of horizontal crack and vertical crack. The horizontal crack appeared in the initial state that was due to moisture ingression route along with the 
substrate from both edge and trap at the middle. Subsequently, the moisture moved up vertically, thus inducing the vertical crack formation, perpendicular to the substrate. The vertical crack was apparently signified from side view of the EMC BGA component.

\section{Acknowledgments}

The authors would like to acknowledge the financial support provided by Western Digital (SanDisk Storage Malaysia Sdn. Bhd.) through a research grant (RR-2020004) and collaboration activities with Universiti Kebangsaan Malaysia (UKM). Authors would like to thank Western Digital Batu Kawan's core investigative team for their technical support in collecting relevant data and findings for this article.

\section{Conflict of interest}

The authors declare no conflict of interest for this paper.

\section{References}

1. S. K. Groothuis, K. G. Heinen and L. Rimpillo, "Effects of mold compound material properties on solder reflow package cracking," Proceed. 1995 IEEE Int. Rel. Phy. Symp., pp. 76-84, 1995, https://doi.org/10.1109/RELPHY.1995.513658

2. Y. Chen and P. Li, "The "popcorn effect" of plastic encapsulated microelectronic devices and the typical cases study," Int. Conf. Qual. Rel. Risk Maint. Safety Eng., pp. 482-485, 2011, https://doi.org/10.1109/ICQR2MSE.2011.5976658

3. J. Lau, R. Chen and C. Chang, "Real-time popcorn analysis of plastic ball grid array packages during solder reflow," 23rd IEEE/CPMT Int. Elect. Manufac. Tech. Symp., (Cat. No.98CH36205), pp. 455-463, 1998,

https://doi.org/10.1109/IEMT.1998.731172

4. N. Ismail, A. Jalar, M. Abu Bakar, N.S. Safee, W.Y Wan Yusoff,. and A. Ismail, "Microstructural evolution and micromechanical properties of SAC305/ CNT/CU solder joint under blast wave condition," Solder. Surf. Mt. Tech., Vol. 33 No. 1, pp. 47-56, 2021,

https://doi.org/10.1108/SSMT-11-2019-0035

5. M.S. Rusdi, M.Z. Abdullah, M.H.H. Ishak,. et al., "Three-dimensional CFD simulation of the stencil printing performance of solder paste," Int J Adv Manuf Technol, vol .108, pp. 3351-3359, 2020, https://doi.org/10.1007/s00170-020-05636-9
6. A. Jalar, M.A. Bakar, \& R. Ismail, "Temperature Dependence of Elastic-Plastic Properties of FinePitch SAC 0307 Solder Joint Using Nanoindentation Approach," Metall Mater Trans A, vol.51, pp. 1221-1228, 2020, https://doi.org/10.1007/s11661-019-05614-1

7. W.Y. Wan Yusoff, N. Ismail, N.S. Safee, A. Ismail, A. Jalar, and M. Abu Bakar, "Correlation of microstructural evolution and hardness properties of 99.0Sn-0.3Ag-0.7Cu (SAC0307) lead-free solder under blast wave condition," Solder Surf Mt Techn, Vol. 31 No. 2, pp. 102-108, 2020,

https://doi.org/10.1108/SSMT-06-2018-0019

8. F. Che Ani, A. Jalar, A.A. Saad, C.Y. Khor, M.A. Abas, Z. Bachok, and N.K. Othman, "Characterization of SAC - x NiO nano-reinforced lead-free solder joint in an ultra-fine package assembly", Solder Surf Mt Tech, Vol. 31 No. 2, pp. 109-124, 2019, https://doi.org/10.1108/SSMT-06-2018-0019

9. A. A. Gallo and R. Munamarty, "Popcorning: a failure mechanism in plastic-encapsulated microcircuits," IEEE Trans Rel, vol. 44, no. 3, pp. 362-367, Sept. 1995, https://doi.org/10.1109/24.406565

10. W. L. Yang and D. M. S. Yin, "The effects of epoxy molding compound composition on the warpage and popcorn resistance of PBGA," Proceed 49th Elect Comp Tech Conf (Cat. No.99CH36299), pp. 721-726, 1999, https://doi.org/10.1109/ECTC.1999.776261

11. T. C. Chai, K. C. Chan, E. H. Wong, X. J. Fan and T. B. Lim, "Achieving crack free package through elimination of type II failure," Proceed 49th Elect Comp Tech Conf (Cat. No.99CH36299), pp. 702707, 1999, https://doi.org/10.1109/ECTC.1999.776256

12. lok-Tong Chong, D. C. C. Lam and Pin Tong, "Measurement of water evaporation rate from epoxy," Int Symp Elect Mater Packag (EMAP2000) (Cat. No.00EX458), pp. 440-443, 2000, https://doi.org/10.1109/EMAP.2000.904196

13. IPC/JEDEC J-STD-033D, Handling, Packing, Shipping and Use of Moisture, Reflow, and Process Sensitive Devices, IPC Standard, April 2018

14. R. Sheng, C. Chen, H. Chen and C. Wang, "A novel temporary adhesive for solder ball attachment in fluxless reflow system," 2017 12th Int Microsyst Packag Assemb Circuits Tech Conf (IMPACT), pp. 66-69, 2017, https://doi.org/10.1109/IMPACT.2017.8255943

15. K. Abhishek, S. David, V.N.N. Trilochan Rambhatla, K.S. Suresh, "Effect of temperature and humidity conditioning on copper leadframe/mold compound interfacial delamination," Microelect Rel, Volume 111, pp.113647, 2020, https://doi.org/10.1016/j.microrel.2020.113647 
16. I. Khalilullah et al., "In-situ characterization of moisture absorption and hygroscopic swelling of silicone/phosphor composite film and epoxy mold compound in LED packaging," 18th Int Conf Therm,Mech Multi-Phy Sim Exp Microelect Microsyst (EuroSimE), pp. 1-9,

https://doi.org/10.1109/EuroSimE.2017.7926275

17. A. Haleh \& G. P. Micheal, "Chapter 5 - Encapsulation Defects and Failures," in Encapsulation Technologies for Electronic Applications, 1st ed., A. Haleh \& G. P. Micheal, Ed. William Andrew Publishing, 2019, pp. 225-285,

https://doi.org/10.1016/B978-0-8155-1576-0.50009-7

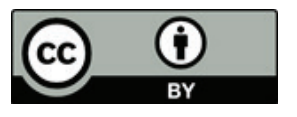

Copyright (c) 2021 by the Authors. This is an open access article distributed under the Creative Commons Attribution (CC BY) License (https://creativecommons.org/licenses/by/4.0/), which permits unrestricted use, distribution, and reproduction in any medium, provided the original work is properly cited.

Arrived: 17. 08. 2021

Accepted: 12. 11. 2021 